\title{
Chromium and phosphorous recovery from polluted water by hydrothermal mineralization
}

\author{
T. Itakura ${ }^{1}$, H. Imaizumi ${ }^{2}$, R. Sasai ${ }^{1,2} \&$ H. Itoh $^{1}$ \\ ${ }^{I}$ EcoTopia Science Institute, Nagoya University, Japan \\ ${ }^{2}$ Graduate School of Engineering, Nagoya University, Japan
}

\begin{abstract}
Detoxification of polluted water containing chromium and phosphorous and its resource recovery were investigated by hydrothermal mineralization using $\mathrm{Ca}(\mathrm{OH})_{2}$ or $\mathrm{CaCl}_{2}$ mineralizers. Under the optimum treatment condition for removing chromic acid (at $473 \mathrm{~K}$, for $2 \mathrm{~h}$ using $\mathrm{CaCl}_{2}$ mineralizer in an in situ sampling-type autoclave), $\mathrm{Cr}^{\mathrm{VI}} \mathrm{O}_{4}{ }^{2-}$ was recovered as $\mathrm{CaCrO}_{4}$ and the concentration in the treated-water was $0.3 \mathrm{mg} / \mathrm{L}$, which was lower than that of the standard of discharged water in Japan. The phosphorous concentration in the treated-water, which was obtained by the hydrothermal treatment at the optimum treatment condition (at $473 \mathrm{~K}$, for $12 \mathrm{~h}$ with $\mathrm{Ca}(\mathrm{OH})_{2}$ mineralizer by using the same sampling-type autoclave), was $0.2 \mathrm{mg} / \mathrm{L}$ regardless of the ionic states. Phosphorous compounds $\left(\mathrm{P}^{\mathrm{III}} \mathrm{O}_{3}{ }^{3-}, \mathrm{P}^{\mathrm{I}} \mathrm{O}_{2}{ }^{3-}\right)$ were recovered as $\mathrm{Ca}\left(\mathrm{HP}^{\mathrm{III}} \mathrm{O}_{3}\right)\left(\mathrm{H}_{2} \mathrm{O}\right)$ precipitate. This result indicates that mono-valent phosphinic acid $\left(\mathrm{P}^{\mathrm{I}} \mathrm{O}_{2}{ }^{3-}\right)$ was oxidized and simultaneously precipitated by the treatment. Therefore, detoxification of the polluted water and resource recovery was accomplished by the hydrothermal mineralization treatment.
\end{abstract}

Keywords: detoxification, resource recovery, hydrothermal mineralization, chromium, phosphorous.

\section{Introduction}

Chromium and phosphorous are widely used as electroplating or metal finishing reagents in modern industries as well as fertilizers, and a large amount of wastewater containing these elements is discharged. The hexa-valent $\mathrm{Cr}$ in such 
as $\mathrm{CrO}_{4}{ }^{2-}$ is well known as one of the toxic metals affecting human health [1]. On the other hand, phosphorous discharged into surface water causes eutrophication of rivers and lakes. Thus, the national effluent standard of Japan (NESJ) of total chromium concentration has been set at $0.5 \mathrm{mg} / \mathrm{dm}^{3}$ and phosphorous set at 16 $\mathrm{mg} / \mathrm{dm}^{3}$. The wastewater containing $\mathrm{Cr}(\mathrm{VI})$ is currently treated by various methods, e.g., chemical precipitation, reverse osmosis, ion exchange and adsorption techniques [2-5], but it is necessary to convert $\mathrm{Cr}(\mathrm{VI})$ into $\mathrm{Cr}$ (III) ions before the treatment. Furthermore, these current processes focus only on the removal of $\mathrm{Cr}(\mathrm{VI})$ from wastewater. On the other hand, the recovery techniques for wastewater containing phosphorous species have been reported only for treating $\mathrm{P}^{\mathrm{V}} \mathrm{O}_{4}{ }^{3-}$ by forming hydroxyapatite. However, phosphorous has different oxidation states such as $\mathrm{P}^{\mathrm{III}} \mathrm{O}_{3}{ }^{3-}$ and $\mathrm{P}^{\mathrm{I}} \mathrm{O}_{2}{ }^{3-}$, especially in the wastewater discharged from the Ni-P plating industry [3, 4]. There are no effective treatments of wastewater containing these chemical species. Chromium and phosphorous are exhaustible and precious industrial resources, so that the recovery system of these elements in aqueous media should be established especially in Japan, which has less natural resources. In our previous study, we found that the hydrothermal mineralization using $\mathrm{Ca}(\mathrm{OH})_{2}$ mineralizer could successfully recover the natural minerals from aqueous media containing oxoanions such as $\mathrm{B}^{\mathrm{III}}(\mathrm{OH})_{4}{ }^{-}, \mathrm{As}^{\mathrm{V}} \mathrm{O}_{4}{ }^{3-}$ and $\mathrm{As}^{\mathrm{III}} \mathrm{O}_{3}{ }^{3-}[5,6]$. This technique is referred to as "geo-mimetic precipitation method", which imitates a natural mechanism for forming minerals from aqueous media under hydrothermal conditions.

In this study, the resource recovery from aqueous media containing chromium and phosphorous oxoanions, such as $\mathrm{CrO}_{4}{ }^{2-} \mathrm{P}^{\mathrm{III}} \mathrm{O}_{3}{ }^{3-}$ and $\mathrm{P}^{\mathrm{I}} \mathrm{O}_{2}{ }^{3-}$ was investigated by hydrothermal mineralization treatment.

\section{Experimental}

\subsection{Batch-type normal hydrothermal mineralization treatment}

Model wastewaters with $\mathrm{Cr}^{\mathrm{VI}} \mathrm{O}_{4}{ }^{2-}, \mathrm{P}^{\mathrm{III}} \mathrm{O}_{3}{ }^{3-}$ or $\mathrm{P}^{\mathrm{I}} \mathrm{O}_{2}{ }^{3-}\left(2000 \mathrm{mg} / \mathrm{dm}^{3}\right)$ were prepared by dissolving $\mathrm{Na}_{2} \mathrm{CrO}_{4}, \mathrm{H}_{3} \mathrm{P}^{\mathrm{III}} \mathrm{O}_{3}$ and $\mathrm{H}_{3} \mathrm{P}^{\mathrm{I}} \mathrm{O}_{2}$ in distilled and deionized water, respectively. These model wastewaters $\left(30 \mathrm{~cm}^{3}\right)$ were sealed in a normal pressure vessel lined with fluorocarbon resin with mineralizer $\mathrm{Ca}(\mathrm{OH})_{2}$ or $\mathrm{CaCl}_{2}$. Hydrothermal treatment was carried out by leaving the vessel in a dry oven for $2-24 \mathrm{~h}$ at a given temperature in the range of $100-200{ }^{\circ} \mathrm{C}$. After the hydrothermal treatment, the vessel was naturally cooled down for $1 \mathrm{~h}$ or cooled down in an ice bath for $15 \mathrm{~min}$. Precipitates were filtered and collected.

\subsection{In situ sampling-type hydrothermal mineralization treatment}

In order to analyze $\mathrm{Cr}$ and $\mathrm{P}$ concentrations under hydrothermal conditions, the apparatus shown in Fig. 1 was used. In this type of apparatus, the liquid-solid separation under hydrothermal condition was achieved by using a sintered metallic mesh filter. Model wastewaters of $60 \mathrm{~cm}^{3}$ were sealed in the pressure 
vessel as shown in Fig. 1 with mineralizer of $1.0 \mathrm{~g} \mathrm{CaCl}_{2}$ (for chromium treatment) or $1.0 \mathrm{~g} \mathrm{Ca}(\mathrm{OH})_{2}$ (for phosphorous treatment). Temperature adjustment was carried out by using a temperature controller (CHINO Corporation, DZ1000).

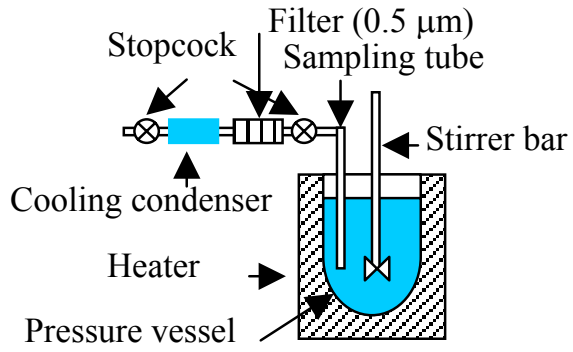

Figure 1: Schematic diagram of in situ sampling-type hydrothermal treatment autoclave.

\subsection{Analysis}

The precipitates were identified by X-ray diffraction (XRD: RIGAKU, Rint2500) using $\mathrm{CuK \alpha}$ radiation. The residual $\mathrm{Cr}$ and $\mathrm{Ca}$ concentration in filtrate after hydrothermal treatment was estimated by inductively couple plasma-atomic emission spectrometry (ICP-AES: perkin-Elmer, Optima3300DV). Concentration of phosphorous ions in the solvent obtained after the hydrothermal treatment was measured by ion chromatograph (IC: Shimadzu, CTO-20AC. Mobile phase; $12 \mathrm{mM} \mathrm{NaHCO}_{3}$, and $0.6 \mathrm{mM} \mathrm{Na}_{2} \mathrm{CO}_{3}$ aqueous solution, Column; him-pack IC-SA2) with the conductivity detector (Shimadzu, CDD-10A).

\section{Results and discussions}

\subsection{Treatment for model wastewater containing $\mathrm{CrO}_{4}{ }^{2-}$}

Figure 2 shows the treatment time dependence of $\mathrm{Cr}$ concentration in the treatedwater by using the batch-type treatment apparatus, where the initial concentration of $\mathrm{Cr}(\mathrm{VI})$ is $2000 \mathrm{mg} / \mathrm{dm}^{3}$ with $0.27 \mathrm{~g}$ of $\mathrm{CaCl}_{2}$ mineralizer, and the treatment temperature is $503 \mathrm{~K}$. Figure 3 shows the XRD pattern of the precipitate obtained by the treatment at $503 \mathrm{~K}$ for $12 \mathrm{~h}$. All the diffraction peaks were identified as $\mathrm{CaCrO}_{4}$ crystal. The $\mathrm{Cr}$ concentration in the treated-water obtained by more than $4 \mathrm{~h}$ treatment was ca. $400 \mathrm{mg} / \mathrm{dm}^{3}$. This result shows that the hydrothermal mineralization treatment is effective to form $\mathrm{CaCrO}_{4}$ and reduce $\mathrm{Cr}$ concentration in aqueous solution. Furthermore, the residual $\mathrm{Cr}(\mathrm{VI})$ concentration decreased from 400 to $200 \mathrm{mg} / \mathrm{dm}^{3}$ by rapid cooling which were carried out by immersing the pressure vessel into an ice bath immediately after the hydrothermal treatment. This result indicates that the solubility of $\mathrm{CaCrO}_{4}$ 
into water under hydrothermal conditions is lower than that under the normal pressure and temperature conditions. Re-dissolution of the formed $\mathrm{CaCrO}_{4}$ would occur during the cooling process due to an increase in its solubility with decreasing temperature of the treated-water. Therefore, suppression of the redissolution of $\mathrm{CaCrO}_{4}$ during cooling process would be achieved effectively to reduce $\mathrm{Cr}$ concentration in the treated-water.

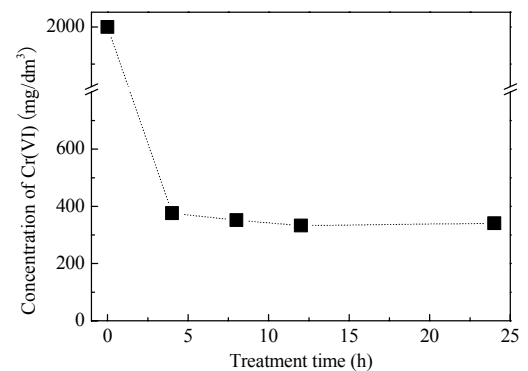

Figure 2:

Dependence of
concentration of $\mathrm{Cr}(\mathrm{VI})$
in the treated-water on
treatment time. Sample:
$30 \mathrm{~cm}^{3}, \mathrm{Cr}(\mathrm{VI}): 2000$
$\mathrm{mg} / \mathrm{dm}^{3}, \mathrm{CaCl}_{2}: 0.27 \mathrm{~g}$,
temperature: $503 \mathrm{~K}$.

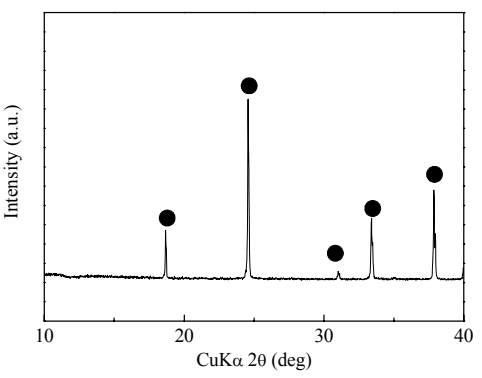

Figure 3:

It is expected from the above results that the solid-liquid separation under hydrothermal condition would be very effective for preventing re-dissolution of the formed mineral. Hydrothermal mineralization treatment was carried out by using the in-situ sampling-type autoclave as shown in Fig. 1. Figure 4 shows the $\mathrm{Cr}$ concentration in the treated-water obtained by three different cooling methods, i.e., (a) by natural cooling for $1 \mathrm{~h}$, (b) by cooling in ice bath for $15 \mathrm{~min}$, (c) by rapid cooling or separation of the precipitates from water under hydrothermal condition (this means cooling time is mostly $0 \mathrm{~min}$ ). $\mathrm{Cr}$ concentration was found $2.4 \mathrm{mg} / \mathrm{dm}^{3}$ after the cooling process of (c). Equilibrium $\mathrm{pH}$ of these sample water before and after the treatment were 7.8. This result indicates that the solid-liquid separation under hydrothermal condition can completely prevent the re-dissolution of formed mineral.

The residual $\mathrm{Cr}$ concentration in the model wastewater treated at $473 \mathrm{~K}$ for 2 $\mathrm{h}$ by in-situ apparatus is plotted against the added amount of $\mathrm{CaCl}_{2}$ in Fig. 5. The $\mathrm{Cr}$ concentration decreased with an increase in the amount of $\mathrm{CaCl}_{2}$ addition, and at the added amount of more than $0.68 \mathrm{~g} \mathrm{CaCl}_{2}$ it reduced down to $0.48 \mathrm{mg} / \mathrm{dm}^{3}$, which was lower than the NESJ $\left(0.5 \mathrm{mg} / \mathrm{dm}^{3}\right)$. It is evident, therefore, that the hydrothermal mineralization treatment with solid-liquid separation under hydrothermal condition is effective to detoxify the wastewater containing $\mathrm{CrO}_{4}{ }^{2-}$ and simultaneously recover $\mathrm{Cr}(\mathrm{VI})$ as natural solid resource, $\mathrm{CaCrO}_{4}$. 

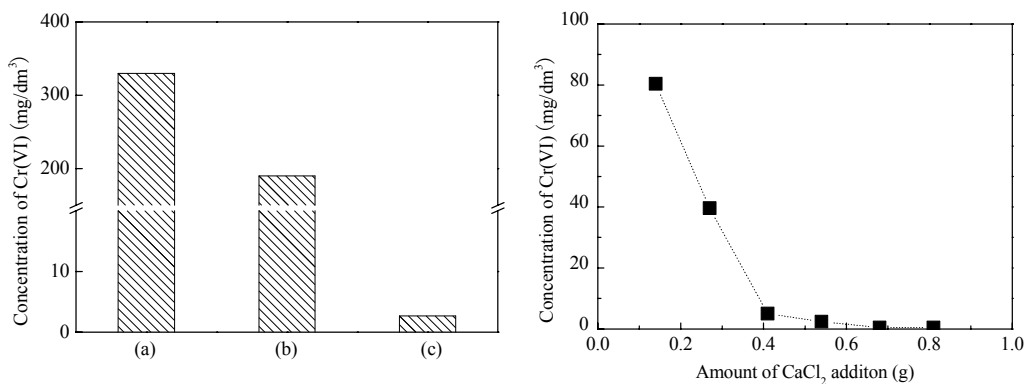

Figure 4:

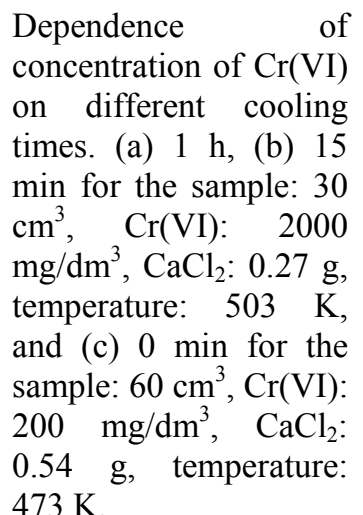

Figure 5: Dependence of $\mathrm{Cr}(\mathrm{VI})$ concentration in the treated water after hydrothermal treatment by using the in-situ apparatus at $473 \mathrm{~K}$ for 2 $\mathrm{h}$ on the added amount of $\mathrm{CaCl}_{2}$. Sample: 60 $\mathrm{cm}^{3}, \quad$ Cr(VI): $\quad 200$ $\mathrm{mg} / \mathrm{dm}^{3}$.

\subsection{Treatment for model wastewater containing $\mathrm{P}^{\mathrm{III}} \mathrm{O}_{3}{ }^{3}$}

The hydrothermal mineralization treatment for model wastewater containing $2000 \mathrm{mg} / \mathrm{dm}^{3} \mathrm{P}^{\mathrm{III}} \mathrm{O}_{3}{ }^{3-}$ with $0.50 \mathrm{~g} \mathrm{Ca}(\mathrm{OH})_{2}$ mineralizer at $150{ }^{\circ} \mathrm{C}$. The $\mathrm{pH}$ and $\mathrm{Ca}$ concentration in aqueous solutions before and after the treatment at any treatment conditions with $\mathrm{Ca}(\mathrm{OH})_{2}$ mineralizer were 12 and $200 \mathrm{mg} / \mathrm{dm}^{3}$ because of solubility of residual $\mathrm{Ca}(\mathrm{OH})_{2}$. Figure 6 shows the treatment time dependence of the phosphorous concentration in treated-water and Figure 7 shows the XRD patterns of the precipitates obtained before and after the treatment. Diffraction peaks of $\mathrm{Ca}\left(\mathrm{HP}^{\mathrm{III}} \mathrm{O}_{3}\right)\left(\mathrm{H}_{2} \mathrm{O}\right)$ was observed as well as those of $\mathrm{Ca}(\mathrm{OH})_{2}$. The concentration of phosphorous before the hydrothermal treatment was ca. 100 $\mathrm{mg} / \mathrm{dm}^{3}$. The decrease in phosphorous concentration only by addition of $\mathrm{Ca}(\mathrm{OH})_{2}$ is derived from the initial formation of $\mathrm{Ca}\left(\mathrm{HP}^{\mathrm{III}} \mathrm{O}_{3}\right)\left(\mathrm{H}_{2} \mathrm{O}\right)$. However, phosphorous concentration was very high compared with NESJ $\left(16 \mathrm{mg} / \mathrm{dm}^{3}\right)$ because of high solubility of $\mathrm{Ca}\left(\mathrm{HP}^{\mathrm{III}} \mathrm{O}_{3}\right)\left(\mathrm{H}_{2} \mathrm{O}\right)$ under the normal pressure and temperature conditions. On the other hand, phosphorous concentration after the hydrothermal treatment was ca. $5.0 \mathrm{mg} / \mathrm{dm}^{3}$, which was lower than the NESJ. Thus, the detoxification of the aqueous media containing $\mathrm{P}^{\mathrm{III}} \mathrm{O}_{3}{ }^{3-}$ was easily accomplished by this treatment. The result also indicates that the solubility of the formed precipitate $\mathrm{Ca}\left(\mathrm{HP}^{\mathrm{III}} \mathrm{O}_{3}\right)\left(\mathrm{H}_{2} \mathrm{O}\right)$ under hydrothermal conditions is lower than that under the normal pressure and temperature conditions. 


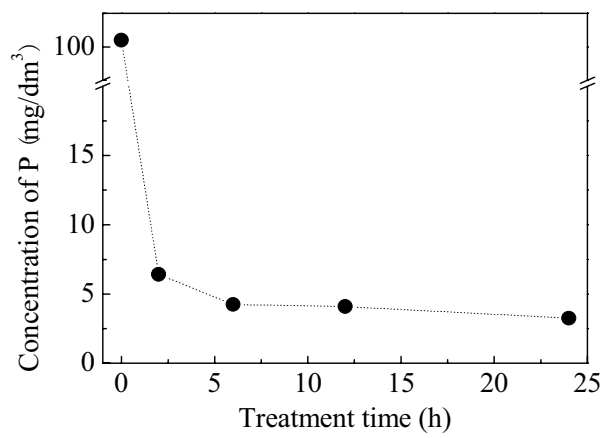

Figure 6:

$$
\begin{aligned}
& \text { Dependence of } \\
& \text { concentration of } \mathrm{P} \text { in the } \\
& \text { treated-water on treatment } \\
& \text { time. } \mathrm{P}^{\mathrm{III}} \mathrm{O}_{3}{ }^{3}: \quad 2000 \\
& \mathrm{mg} / \mathrm{dm}_{3}, \mathrm{Ca}(\mathrm{OH})_{2}: 0.50 \mathrm{~g} \text {, } \\
& 150{ }^{\circ} \mathrm{C} \text {. }
\end{aligned}
$$

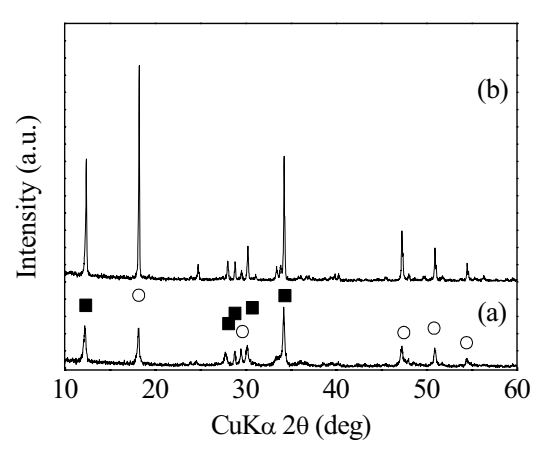

Figure 7: XRD patterns of the precipitates (a) before and (b) after the treatment for $24 \mathrm{~h}$ at $150{ }^{\circ} \mathrm{C}$. ( $\left.\mathrm{O}\right) \mathrm{Ca}(\mathrm{OH})_{2}$, (a) $\mathrm{Ca}\left(\mathrm{HPO}_{3}\right)\left(\mathrm{H}_{2} \mathrm{O}\right)$.

\subsection{Treatment for model wastewater containing $\mathrm{P}^{\mathrm{I}} \mathrm{O}_{2}{ }^{3}$}

Figure 8 shows the result of hydrothermal mineralization treatment for aqueous solution containing $\mathrm{P}^{\mathrm{I}} \mathrm{O}_{2}{ }^{3-}\left(\mathrm{P}: 2000 \mathrm{mg} / \mathrm{dm}^{3}\right)$ at 100,150 and $200{ }^{\circ} \mathrm{C}$ with $0.50 \mathrm{~g}$ $\mathrm{Ca}(\mathrm{OH})_{2}$ mineralizer. The concentration of phosphorous did not decrease before the hydrothermal treatment, i.e., only by the addition of $\mathrm{Ca}(\mathrm{OH})_{2}$. However, phosphorous concentration in the treated water at $200{ }^{\circ} \mathrm{C}$ decreased to 13.3 $\mathrm{mg} / \mathrm{dm}^{3}$, which was lower than the NESJ. Therefore, the hydrothermal mineralization treatment is definitely effective for removing $\mathrm{P}^{\mathrm{I}} \mathrm{O}_{2}{ }^{3-}$ in the polluted water. Figure 9 shows the XRD patterns of precipitates obtained after the treatment with $0.50 \mathrm{~g} \mathrm{Ca}(\mathrm{OH})_{2}$ at various temperatures. The precipitates formed was $\mathrm{Ca}\left(\mathrm{HP}^{\mathrm{III}} \mathrm{O}_{3}\right)\left(\mathrm{H}_{2} \mathrm{O}\right)$, which was the same compound as the precipitate obtained by the treatment for $\mathrm{P}^{\mathrm{III}} \mathrm{O}_{3}{ }^{3-}$ (see Fig. 7). This result suggested that $\mathrm{P}^{\mathrm{I}} \mathrm{O}_{2}{ }^{3-}$ was oxidized from mono-valence to tri-valence by $\mathrm{H}_{2} \mathrm{O}$ molecules under the hydrothermal conditions. It was already found in our previous study [7, 8], that $\mathrm{H}_{2} \mathrm{O}$ could play the role of oxidant under hydrothermal conditions. At the optimal treatment condition, the present method can reduce the concentration of $\mathrm{P}^{\mathrm{I}} \mathrm{O}_{2}{ }^{3-}$ less than the NESJ, and at the same time $\mathrm{P}^{\mathrm{I}} \mathrm{O}_{2}{ }^{3-}$ in the aqueous media can be finally recovered as a natural resource, $\mathrm{Ca}\left(\mathrm{HP}^{\mathrm{III}} \mathrm{O}_{3}\right)\left(\mathrm{H}_{2} \mathrm{O}\right)$.

Along with the treatment for $\mathrm{CrO}_{4}{ }^{2-}$, it is expected that the re-dissolution of the formed $\mathrm{Ca}\left(\mathrm{HP}^{\mathrm{III}} \mathrm{O}_{3}\right)\left(\mathrm{H}_{2} \mathrm{O}\right)$ would occur during the cooling process, because its solubility under the normal pressure and temperature conditions is higher than that under hydrothermal condition. Thus, the solid-liquid separation under hydrothermal condition would be effective for reducing phosphorous concentration in the treated-water. Figure 10 shows the results of hydrothermal mineralization treatment using a normal batch type autoclave and an in-situ 


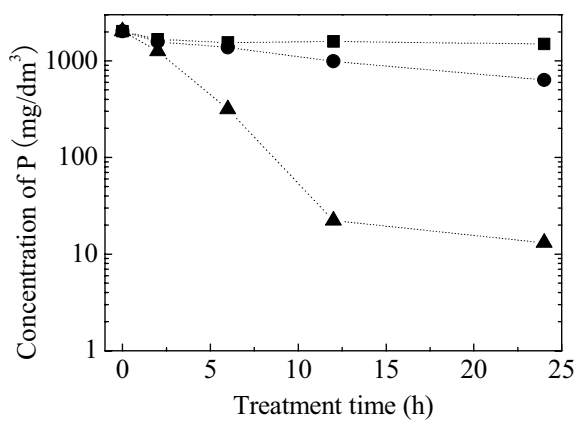

Figure 8: Dependence of concentration of $\mathrm{P}$ in the treated-water on the treatment time. $\mathrm{P}^{\mathrm{I}} \mathrm{O}_{2}{ }^{3-}: 2000 \mathrm{mg} / \mathrm{dm}^{3}$, $\mathrm{Ca}(\mathrm{OH})_{2}: 0.50 \mathrm{~g},(\mathbf{\bullet})$ $100{ }^{\circ} \mathrm{C},(\bullet) 150{ }^{\circ} \mathrm{C}$, (A) $200^{\circ} \mathrm{C}$.

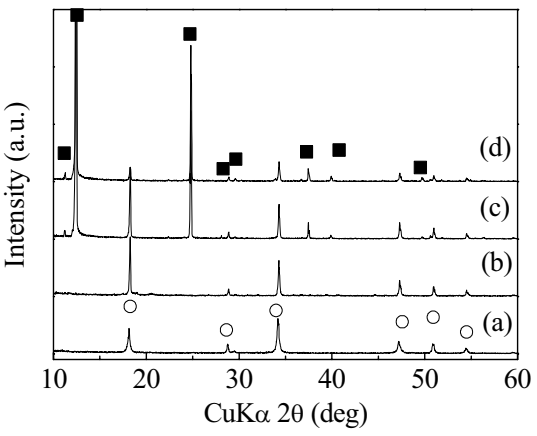

Figure 9: XRD patterns of the precipitates (a) before and after the treatment for $24 \mathrm{~h},(\mathrm{~b})$ at $100{ }^{\circ} \mathrm{C}$, (c) at $150{ }^{\circ} \mathrm{C}$, (d) at 200 ${ }^{\circ} \mathrm{C}$; (०) $\mathrm{Ca}(\mathrm{OH})_{2}$, (घ) $\mathrm{Ca}\left(\mathrm{HP}^{\mathrm{III}} \mathrm{O}_{3}\right)\left(\mathrm{H}_{2} \mathrm{O}\right)$.

sampling-type autoclave (see Fig. 1). As a result, phosphorous concentration after the treatment for $12 \mathrm{~h}$ was $0.20 \mathrm{mg} / \mathrm{dm}^{3}$, which indicated that the separation of precipitates from the treated-water under hydrothermal conditions improved the phosphorous recovery yield. This treatment can completely prevent the re-dissolution of the formed minerals during cooling process. Therefore, the hydrothermal treatment using the in-situ sampling-type autoclave is effective to detoxify the wastewater and recover phosphorous in wastewater as natural resources.

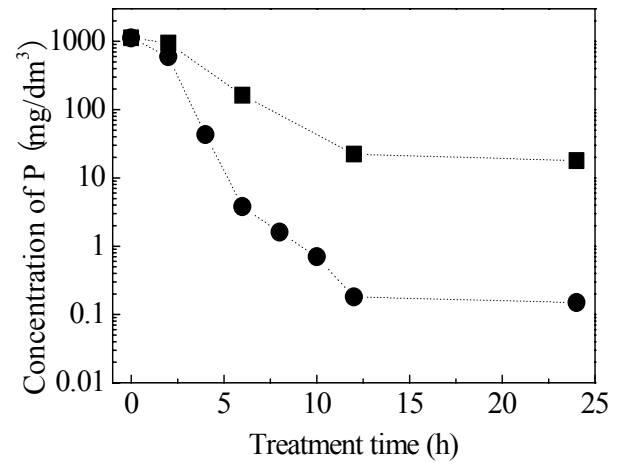

Figure 10: Dependence of concentration of $\mathrm{P}$ in the treated-water on the treatment time $200{ }^{\circ} \mathrm{C} . \mathrm{P}^{\mathrm{III}} \mathrm{O}_{3}{ }^{3-}: 1000 \mathrm{mg} / \mathrm{dm}^{3}, \mathrm{P}^{\mathrm{I}} \mathrm{O}_{3}{ }^{3-}: 1000$ $\mathrm{mg} / \mathrm{dm}^{3}, \mathrm{Ca}(\mathrm{OH})_{2}: 1.0 \mathrm{~g},(\boldsymbol{\bullet})$ normal batch, $(\bullet)$ in-situ. 


\section{Conclusions}

Precipitation recovery of $\mathrm{CrO}_{4}{ }^{2-}, \mathrm{P}^{\mathrm{III}} \mathrm{O}_{3}{ }^{3-}$ or $\mathrm{P}^{\mathrm{I}} \mathrm{O}_{2}{ }^{3-}$ from wastewater was investigated. As a result, detoxification of aqueous media and resource recovery was accomplished by using hydrothermal mineralization method. It was found that hydrothermal mineralization with $\mathrm{CaCl}_{2}$ mineralizer could recover $\mathrm{CrO}_{4}{ }^{2-}$ as a natural resource of $\mathrm{CaCrO}_{4}$. Furthermore, solid-liquid separation under hydrothermal condition was very effective to improve the recovery yield of $\mathrm{Cr}$, because the solubility of formed $\mathrm{CaCrO}_{4}$ is very low under hydrothermal condition. $\mathrm{Cr}$ concentration in the treated-water at optimum treatment condition was $0.48 \mathrm{mg} / \mathrm{dm}^{3}$, which was less than NESJ. $\mathrm{P}^{\mathrm{III}} \mathrm{O}_{3}{ }^{3-}$ was easily recovered as $\mathrm{Ca}\left(\mathrm{HP}^{\mathrm{III}} \mathrm{O}_{3}\right)\left(\mathrm{H}_{2} \mathrm{O}\right)$. $\mathrm{P}^{\mathrm{I}} \mathrm{O}_{2}{ }^{3-}$ was also recovered as $\mathrm{Ca}\left(\mathrm{HP}^{\mathrm{III}} \mathrm{O}_{3}\right)\left(\mathrm{H}_{2} \mathrm{O}\right)$ by the hydrothermal mineralization and hydrothermal oxidation. Solid-liquid separation under hydrothermal conditions was also effective for treating phosphoric species in wastewater. Thus, it is considered that the present hydrothermal mineralization method is very promising technique as one of the practical wastewater treatment techniques.

\section{References}

[1] C. Raji and T.S. Anirudhan, Indian J. Chem. Technol. 4 (1996) 228-236.

[2] Siddiqui, B.A., P.P. Sharma and M. Sultan, Ind. J. Environ. Prot., 19 (1999) 846-852.

[3] Hanra, A. M. and S. Prabhakar, Ind. J. Environ. Prot., 1 (1996) 35-40.

[4] G. McKay, M.S. Otterburn and A.G. Sweeny, Water Res. 15 (1981) 327331.

[5] L. M. Abrantes, M. C. Olweira and E. Vieil, Electrochimica Acta 41 (9) (1994) 1515-1524.

[6] M. Cristina Oliveira and A.M. Botelho do Rego, Journal of Alloys and Compounds 425 (2006) 64-68.

[7] T. Itakura, R. Sasai and Hideaki Itoh, Water Research 39 (2005) 2543-2548.

[8] T. Itakura, R. Sasai and Hideaki Itoh, Journal of Hazardous Materials 146 (2007) 328-333. 